\title{
High-purity $\mathrm{Ti}_{2} \mathrm{AIC}$ Powder: Preparation and Application in Ag-based Electrical Contact Materials
}

\author{
DING Jianxiang ${ }^{1}$, HUANG Peiyan ${ }^{1}$, ZHA Yuhui ${ }^{1}$, WANG Dandan ${ }^{2}$, \\ ZHANG Peigen $^{2}$, TIAN Wubian ${ }^{2}$, SUN Zhengming ${ }^{2}$
}

\begin{abstract}
(1. Key Laboratory of Green Fabrieation and Surface Technology of Advanced Metal Materials, Ministry of Education, School of Materials Science and Engineering, Anhui University of Technology, Ma'anshan 243002, China; 2. School of Materials Science and Engineering, Southeast University, Nanjing 211189, China)
\end{abstract}

\begin{abstract}
Ag-based electrical contact is the "heart" of low-voltage switch, and the Cd toxicity has long been a haunting problem. It is the research focus of the low-voltage switch to find new environment-friendly electrical contact materials. Starting from the design of reinforcement for Ag-based electrical contact in this work, the high-purity $\mathrm{Ti}_{2} \mathrm{AlC}$ powder (99.2\%) was synthesized by a simple and fast pressureless technique. $\mathrm{Ag} / \mathrm{Ti}_{2} \mathrm{AlC}$ composite electrical contact material was also prepared with homogeneous structure, good bonding between $\mathrm{Ag}$ and $\mathrm{Ti}_{2} \mathrm{AlC}$ particles, high relative density (95.7\%), moderate hardness (96HV), satisfactory electrical conductivity (low resistivity of $79.5 \mathrm{n} \Omega \cdot \mathrm{m}$ ), and favorable arc erosion resistance (mass loss of $4.4 \%$ after 5610 arc discharging cycles). These excellent structure and properties of $\mathrm{Ag} / \mathrm{Ti}_{2} \mathrm{AlC}$ composite are mainly attributed to the good thermal and electrical conductivity of $\mathrm{Ti}_{2} \mathrm{AlC}$ and the good wettability between $\mathrm{Ag}$ and $\mathrm{Ti}_{2} \mathrm{AlC}$. This composite is expected to replace the conventional electrical contact materials in the future.
\end{abstract}

Key words: $\mathrm{Ti}_{2} \mathrm{AlC}$; electrical contact; metal-ceramic composite; conductivity; wettability; arc erosion resistance

As a core component, Ag-based electrical contact is widely used in the low-voltage switching devices, such as contactors, circuit breakers, and relays ${ }^{[1]}$. Contact material is exposed to the extremely high temperature and oxygen-enriched environment during the making and breaking of circuit, thus its performance directly determines the life of electrical appliances. In the process of contacting, contact is subjected to various working conditions with different current, voltage, temperature, humidity, etc. Consequently, properties such as high electrical and thermal conductivity, low contact resistance, moderate hardness, good machinability, high resistance to oxidation and arc erosion are the prerequisites for electrical contact materials ${ }^{[2]}$. $\mathrm{Ag} / \mathrm{CdO}$ has been the preferred material for the electrical contacts since the early $20^{\text {th }}$ century, but the toxicity of $\mathrm{Cd}$ brings a series of serious problems ${ }^{[3-4]}$. Current $\mathrm{Cd}$-free contact materials $\left(\mathrm{Ag} / \mathrm{SnO}_{2}{ }^{[5]} 、 \mathrm{Ag} / \mathrm{ZnO}_{2}{ }^{[6]} 、 \mathrm{Ag} / \mathrm{CuO}^{[7]} 、 \mathrm{Ag} / \mathrm{C} 、 \mathrm{Ag} / \mathrm{W}^{[8]}\right.$ 、 $\mathrm{Ag} / \mathrm{Ni}^{[9]}$, etc.) cannot replace $\mathrm{Ag} / \mathrm{CdO}$ completely due to their various drawbacks in the aspects of structure and property. Thus, finding the adequate environment- friendly reinforcement to replace $\mathrm{Ag} / \mathrm{CdO}$ is urgent.

Recently, MAX phase materials (chemical formula of $\mathrm{M}_{n+1} \mathrm{AX}_{n}$, where $\mathrm{M}$ is early transition metal, $\mathrm{A}$ is mainly group A element, $\mathrm{X}$ is $\mathrm{C}$ or $\mathrm{N}$ ), with combined properties of both metal and ceramic, received great attention from academia and industry ${ }^{[10-11]} \cdot \mathrm{Ti}_{2} \mathrm{AlC}$ is one member of this MAX phase family with typically lamellar structure, light weight $\left(4.11 \mathrm{~g} / \mathrm{cm}^{3}\right)$, high electrical conductivity (resistivity of $0.36 \mu \Omega \cdot \mathrm{m}$ ), thermal conductivity $\left(46 \mathrm{~W} \cdot \mathrm{m}^{-1} \cdot \mathrm{K}^{-1}\right)$, and excellent machinability like metals, good resistance to high-temperature and oxidation like ceramics ${ }^{[11]}$. $\mathrm{Ti}_{2} \mathrm{AlC}$ is considered as a potential reinforcement material, whose properties meet the requirement of Ag-based electrical contact materials. Over the past few years, Sun and Liu, et al successfully prepared Ag-based composites with the reinforcements of $\mathrm{Ti}_{3} \mathrm{SiC}_{2}{ }^{[12]}$, $\mathrm{Ti}_{3} \mathrm{AlC}_{2}{ }^{[13-16]}$, and $\mathrm{Ti}_{2} \mathrm{SnC}^{[17-18]}$, and systematically studied their phase, microstructure, and properties. Besides the basic properties of MAX phase family, $\mathrm{Ti}_{2} \mathrm{AlC}$ has the outstanding resistance to oxidation. Hence, $\mathrm{Ag} / \mathrm{Ti}_{2} \mathrm{AlC}$ ( $\mathrm{Ag} / \mathrm{TAC})$ composite is expected to be the potential sub-

Received date: 2019-05-23; Revised date: 2019-07-14

Foundation item: National Natural Science Foundation of China (51731004, 51671054); Fundamental Research Funds for the Central Universities in China (2242018K40108; 2242018K40109); Natural Science Foundation of Jiangsu Province (BK20181285); Youth Research Fund Project of Anhui University of Technology

Biography: DING Jianxiang(1987-), male, PhD candidate. E-mail: 15295562390@163.com; jxding@ahut.edu.cn 丁健翔(1987-), 男, 博士研究生. E-mail: 15295562390@163.com; jxding@ahut.edu.cn

Corresponding author: TIAN Wubian, associate professor. E-mail: wbtian@seu.edu.cn; SUN Zhengming, professor. E-mail: zmsun@seu.edu.cn 田无边, 副教授.E-mail: wbtian@seu.edu.cn; 孙正明, 教授.E-mail: zmsun@seu.edu.cn 
stitute to $\mathrm{Ag} / \mathrm{CdO}$.

There are two key points need to be paid attention in the studying of $\mathrm{Ag} / \mathrm{TAC}$ composites. First, the impure phases affect the density, structure, interface, and properties of the composites. Thus, preparing high-purity $\mathrm{Ti}_{2} \mathrm{AlC}$ powder is particularly important before studying the Ag/TAC composite electrical contact materials. The synthesis of $\mathrm{Ti}_{2} \mathrm{AlC}$ bulk and powder by using hot pressing (HP) ${ }^{[19]}$, hot isostatic pressing (HIP $)^{[20]}$, spark plasma discharging $(\mathrm{SPS})^{[21]}$, and self-propagated sintering $(\mathrm{SHS})^{[22]}$ has been reported. These techniques, however, cost highly with complex process, and produce $\mathrm{Ti}_{2} \mathrm{AlC}$ with many impure phases such as $\mathrm{TiC}$, Ti-Al compounds, and $\mathrm{Ti}_{3} \mathrm{AlC}_{2}$. In contrast, the pressureless sintering technique (PLS) is simple, efficient, and low-cost ${ }^{[23]}$, which is more meaningful for the practical application. In addition, the preparation, microstructure, interface bonding, and electrical contacting property of composite can be largely affected by the wettability between reinforcement and $\mathrm{Ag}$ matrix. Therefore, the wetting behavior of Ag and $\mathrm{Ti}_{2} \mathrm{AlC}$ is a key issue for the research and application of $\mathrm{Ag} / \mathrm{TAC}$ composites.

The purpose of this work is to synthesize the high-purity $\mathrm{Ti}_{2} \mathrm{AlC}$ powder by using pressureless technique, and study the effect of process parameters on the purity and microstructure of $\mathrm{Ti}_{2} \mathrm{AlC}$. Then the wettability, microstructure, mechanical properties, electrical properties, and arc erosion resistance of $\mathrm{Ag} / \mathrm{TAC}$ composites were studied, and its application potential were also discussed.

\section{Experimental}

\subsection{Synthesis of $\mathrm{Ti}_{2} \mathrm{AlC}$ powder}

Powders of TiC ( 5 $\mu \mathrm{m}, 99.0 \%)$, Ti ( $50 \mu \mathrm{m}, 99.99 \%)$, and $\mathrm{Al}(\sim 50 \mu \mathrm{m}, 99.7 \%)$ were weighed according to stoichiometric ratio and then were totally homogenized in the three-dimensional mixer (Turbula T2F, WAB, Switzerland) for $24 \mathrm{~h}$. Mixture powders were directly heated to the setting temperature for $1 \mathrm{~h}$ at a heating rate of $10{ }^{\circ} \mathrm{C} / \mathrm{min}$ under the protection of flowing Ar gas (99.999\% purity).

\subsection{Wetting test of $\mathrm{Ag} / \mathrm{Ti}_{2} \mathrm{AlC}$}

$\mathrm{Ti}_{2} \mathrm{AlC}$ bulk (a relative density of $99.6 \%$ ) was prepared by using SPS (heated to $1300{ }^{\circ} \mathrm{C}$ at a heating rate of $50{ }^{\circ} \mathrm{C} / \mathrm{min}$ and held for $20 \mathrm{~min}$ with a applied pressure of $50 \mathrm{MPa}$ ). The prepared composite bulk was cut into small disc (10 mm diameter) with a polished surface. Ag $\operatorname{rod}(99.99 \%$ purity, $2 \mathrm{~mm}$ in diameter, $2 \mathrm{~mm}$ in length) was placed with the disc into the high temperature contact instrument (OCA25HTV, Dataphysics, Germany), then was heated to $1120{ }^{\circ} \mathrm{C}$ for $10 \mathrm{~min}$ at a heating rate of $8{ }^{\circ} \mathrm{C} / \mathrm{min}$. The wetting angle data of molten $\mathrm{Ag}$ on the surface of $\mathrm{Ti}_{2} \mathrm{AlC}$ were recorded by the software (SCA20).

\subsection{Preparation of $\mathbf{A g} / \mathbf{T i}_{2} \mathbf{A l C}$ composite}

Powders of $\mathrm{Ag}(\sim 10 \mu \mathrm{m}, 99.99 \%)$ and $\mathrm{Ti}_{2} \mathrm{AlC}(\sim 20 \mu \mathrm{m}$, $99.2 \%)$ were weighed with a mass ratio of 9:1. Mixture powders were wet ball milled for $0.5 \mathrm{~h}$ with the medium of alcohol. Dried mixture were cold-pressed at $800 \mathrm{MPa}$ into green body ( $15 \mathrm{~mm}$ in diameter, $3 \mathrm{~mm}$ in thickness). Samples were heated to $800{ }^{\circ} \mathrm{C}$ for $2 \mathrm{~h}$ in a tube furnace with a heating rate of $5{ }^{\circ} \mathrm{C} / \mathrm{min}$.

\subsection{Arc erosion experiment}

$\mathrm{Ag} / \mathrm{TAC}$ bulk was cut into the contacts $(1.5 \mathrm{~mm}$ in thickness, $7 \mathrm{~mm}$ in diameter), then these contacts were welded with copper bases, finally were installed into a commercial contactor (CJX-50, China). The electric arc discharging experiment was carried out at the low voltage electrical apparatus test center of Shanghai Electrical Research Institute. The arc erosion resistance of Ag/TAC contacts were tested with the following experimental parameter (set according to the national standard GB14048.4-2010): AC-3 inductive load, $400 \mathrm{~V}$ voltage, 100 A circuit, $50 \mathrm{~Hz}$ coil frequency, 600 cycles/h operation frequency.

\subsection{Characterizations}

The phases were characterized by X-ray diffraction (XRD) (Bruker-AXS D8, Germany) with a scan rate of $10\left(^{\circ}\right) / \mathrm{min}$. The morphologies of $\mathrm{Ti}_{2} \mathrm{AlC}$ powder and $\mathrm{Ag} / 10 \mathrm{TAC}$ composites were obtained by a field-emission scanning electron microscopy (FE-SEM) (Sirion 200, FEI/Fhilips, Netherlands), and their chemical component were tested and analyzed by the energy dispersed X-ray spectrometer (EDS) (AZtes X-MAX 80, Germany). The density of Ag/10TAC bulk was directly tested with the densimeter (DH-300, China, $0.001 \mathrm{~g} / \mathrm{cm}^{3}$ accuracy). The hardness of Ag/10TAC composite was measured by the Vickers microhardness tester (FM-700, Japan, $1 \mathrm{~kg}$ pressure, holding time of $5 \mathrm{~s}$ ). The resistance of Ag/10TAC bulk was obtained by using the instrument (METRAHIT $27 \mathrm{I}$, Germany, $0.001 \mathrm{~m} \Omega$ accuracy), and then its resistivity was calculated according to the four probe principle. Mass loss of the Ag/TAC contact after arc erosion was obtained by using the electronic balance (BT25S, Sartorius, Germany, $0.01 \mathrm{mg}$ accuracy). Area loss of the contact after arc erosion was calculated with the metallographic microscope analysis software (LAS V4.8, Leica, Germany).

\section{Results and discussion}

\subsection{High-purity $\mathrm{Ti}_{2} \mathrm{AIC}$ powders}

During the preparation of $\mathrm{Ti}_{2} \mathrm{AlC}$, Al first melts due to its low melting point and provides a liquid environment 
for the subsequent reactions. Vaporization of $\mathrm{Al}$ at high temperature leads to the loss of $\mathrm{Al}$ in the raw materials. Therefore, appropriate increase of Al content is the premise to ensure the chemical reaction according to the stoichiometric ratio of raw powder. In Table 1, the content of $\mathrm{TiC}$ and $\mathrm{Ti}$ in the raw materials remains unchanged, excessive $\mathrm{Al}$ are added to the raw materials to study the effect of $\mathrm{Al}$ content on the purity of $\mathrm{Ti}_{2} \mathrm{AlC}$ powder.

X-ray diffraction was carried out to identify the phase composition of the as-prepared $\mathrm{Ti}_{2} \mathrm{AlC}$ powder. As shown in Fig. 1, peaks of $\mathrm{Ti}_{2} \mathrm{AlC}$ were detected in all four samples, however, some impure phases like $\mathrm{Ti}_{3} \mathrm{AlC}_{2}$ and $\mathrm{TiC}$ were also detected in the final sample. Diffraction peak of the impure phase increases with the increase of the Al content in the raw materials. The purity of $\mathrm{Ti}_{2} \mathrm{AlC}$ in the four samples are calculated according to the integral area of the main peak of the main phase $\mathrm{e}^{[24]}$, as shown in Table 1. The result shows that the highest purity of $\mathrm{Ti}_{2} \mathrm{AlC}$ powder reaches $77.5 \%$ (Sample S1) when the molar ratio of $\mathrm{Al}$ is 1.05 in the starting raw material.

Based on the Sample S1, the contents of Ti and $\mathrm{Al}$ in the raw materials remain unchanged, while the content of $\mathrm{C}$ reduces gradually. Four samples (Table 2) were designed to study the effect of C-deficiency in the raw material on the purity of $\mathrm{Ti}_{2} \mathrm{AlC}$ powder. As shown in Fig. 2, XRD result shows that $\mathrm{Ti}_{3} \mathrm{AlC}_{2}$ and $\mathrm{TiC}$ phases are hardly detected in Sample $\mathrm{S} 5$, and the purity of $\mathrm{Ti}_{2} \mathrm{AlC}$ powder was calculated as $99.2 \%$ (Table 2), indicating that the $\mathrm{C}$-deficiency in the raw materials facilitates the generation of more $\mathrm{Ti}_{2} \mathrm{AlC}$ phase. However, the further increase of $\mathrm{C}$ content in the raw material in turn leads to the

Table 1 Molar ratio of raw material powder $\mathrm{TiC} / \mathrm{Ti} / \mathrm{xAl}$

\begin{tabular}{ccc}
\hline Sample & Composition, $x$ & Purity $/ \%$ \\
\hline S1 & 1.05 & 77.5 \\
S2 & 1.10 & 57.9 \\
S3 & 1.15 & 41.4 \\
S4 & 1.20 & 31.5 \\
\hline
\end{tabular}

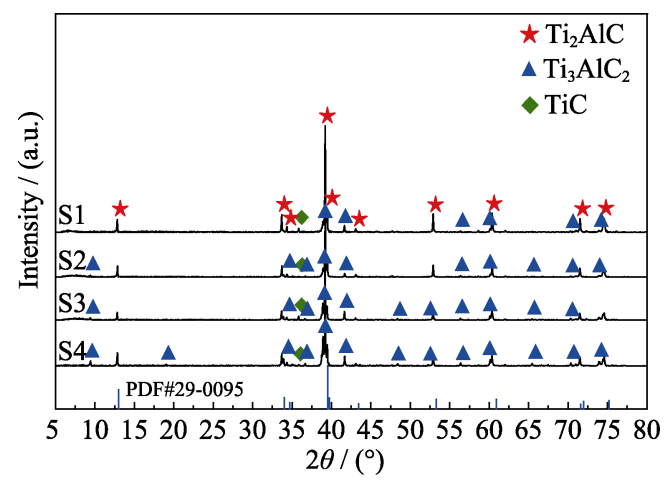

Fig. 1 XRD patterns of samples with different $\mathrm{Al}$ contents
Table 2 Molar ratio of raw material powder $(2-x) \mathrm{TiC} / x \mathrm{Ti} / 1.05 \mathrm{Al}$

\begin{tabular}{ccc}
\hline Sample & Composition, $x$ & Purity $/ \%$ \\
\hline S1 & 1.00 & 77.5 \\
S5 & 1.05 & 99.2 \\
S6 & 1.10 & 92.3 \\
S7 & 1.15 & 91.7 \\
\hline
\end{tabular}

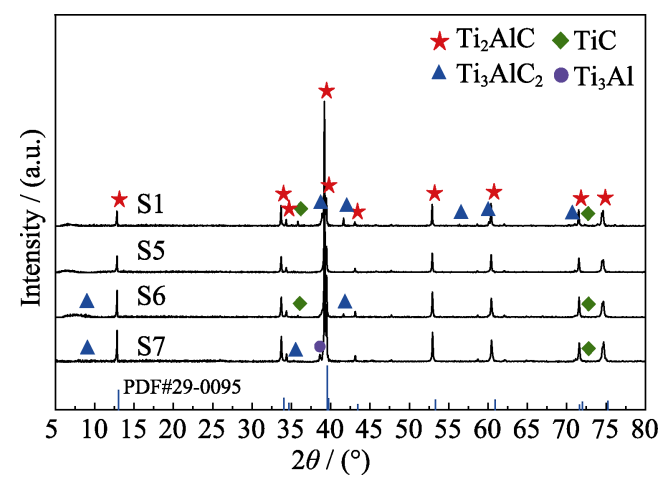

Fig. 2 XRD patterns of samples with different $\mathrm{C}$ contents

decomposition of $\mathrm{Ti}_{2} \mathrm{AlC}$ into $\mathrm{TiC}$ and $\mathrm{Ti}-\mathrm{Al}$ compound (Sample S6, S7). In addition, little $\mathrm{Ti}_{3} \mathrm{AlC}_{2}$ is also detected in the final samples. The purities of both Sample 6 and Sample 7 are less than $93 \%$, which indicates that the severe shortage of $\mathrm{C}$ in the raw material deteriorates the purity of $\mathrm{Ti}_{2} \mathrm{AlC}$ powder.

The morphologies of samples with different $\mathrm{C}$ contents are displayed in Fig. 3. The powders of Sample S1, S6 and S7 exhibit irregular shape and their surfaces were covered by many adherent particles with a small size of $0.2-0.8 \mu \mathrm{m}$ (Fig. 3(a-b, e-h). It is reported that the existence of two M layers in every two A layers leads to the formation of layered crystal structure of 211MAX phase ${ }^{[11]}$. But the more $\mathrm{C}$ and excessive $\mathrm{Al}$ in raw material powders generate the impurity phase (TiC, Ti-Al compounds, etc.) in addition to the main phase $\mathrm{Ti}_{2} \mathrm{AlC}$, thus leading to the destruction of the crystal structure of $\mathrm{Ti}_{2} \mathrm{AlC}$ and its poor morphology with nonstandard layered structure. In contrast, powder of Sample S5 shows standard lamellar structure of MAX without any adherent particles (Fig. 3(c, d)), indicating that the $\mathrm{Ti}_{2} \mathrm{AlC}$ powder in Sample S5 have superior purity. This result presents that the slightly deficient $\mathrm{C}$ and a little more $\mathrm{Al}$ in raw materials do not produce impurity phase and the prepared $\mathrm{Ti}_{2} \mathrm{AlC}$ have complete crystal structure, which is consistent with that of XRD result in Fig. 2.

Sintering temperature is another important factor for the phase transition and morphology evolution of the $\mathrm{Ti}_{2} \mathrm{AlC}$ powder during the synthesizing process. Raw powder with the composition of $0.95 \mathrm{TiC} / 1.05 \mathrm{Ti} / 1.05 \mathrm{Al}$ is heated to different temperatures, as shown in Table 3. XRD result shows that the final powder contains a large 

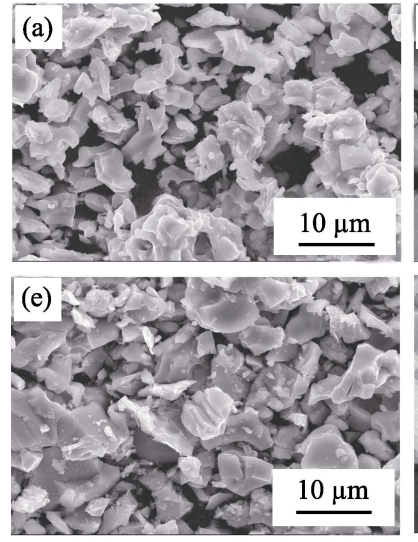
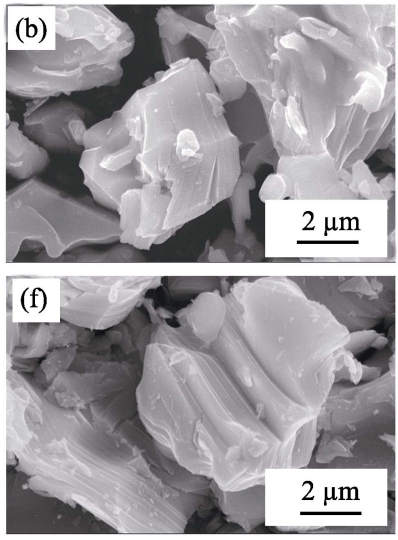
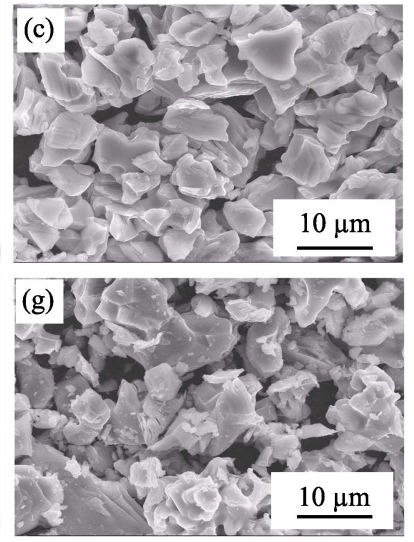
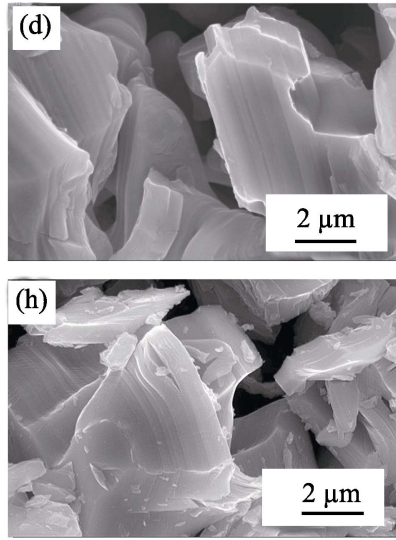

Fig. 3 SEM images of samples with different $\mathrm{C}$ contents (a, b) S1; (c, d) S5; (e, f) S6; (g, h) S7

amount of $\mathrm{TiC}$ and $\mathrm{Ti}-\mathrm{Al}$ compounds due to the insufficient reaction when synthestic temperature is below $1400{ }^{\circ} \mathrm{C}$ (Fig. 4). Once the temperature exceeds $1500{ }^{\circ} \mathrm{C}$, the synthesized $\mathrm{Ti}_{2} \mathrm{AlC}$ phase largely decomposes into $\mathrm{TiC}$ and Ti-Al compounds, and merely produces little $\mathrm{Ti}_{3} \mathrm{AlC}_{2}$. At $1400{ }^{\circ} \mathrm{C}$, the high-purity $\mathrm{Ti}_{2} \mathrm{AlC}$ is stable, and no impure phase is detected.

In summary, appropriate increase of $\mathrm{Al}$ and slight reduction of $\mathrm{C}$ in the raw material facilitate the generation of $\mathrm{Ti}_{2} \mathrm{AlC}$ phase in the final powder. But excessively low and high temperature hinder the purity improvement of $\mathrm{Ti}_{2} \mathrm{AlC}$ powder. In order to obtain high-purity $\mathrm{Ti}_{2} \mathrm{AlC}$ powder, the optimal synthesis process parameters is concluded as: a raw powder with composition of $0.95 \mathrm{TiC} / 1.05 \mathrm{Ti} / 1.05 \mathrm{Al}$, sintered at $1400{ }^{\circ} \mathrm{C}$ for $1 \mathrm{~h}$ under pressureless condition.

Table 3 Preparation of $\mathrm{Ti}_{2} \mathrm{AlC}$ powder from $0.95 \mathrm{TiC} / 1.05 \mathrm{Ti} / 1.05 \mathrm{Al}$ at different temperatures

\begin{tabular}{ccc}
\hline Sample & Temperature $/{ }^{\circ} \mathrm{C}$ & Purity $/ \%$ \\
\hline S8 & 1200 & 16.3 \\
S9 & 1300 & 35.7 \\
S10 & 1400 & 99.2 \\
S11 & 1500 & 81.8 \\
\hline
\end{tabular}

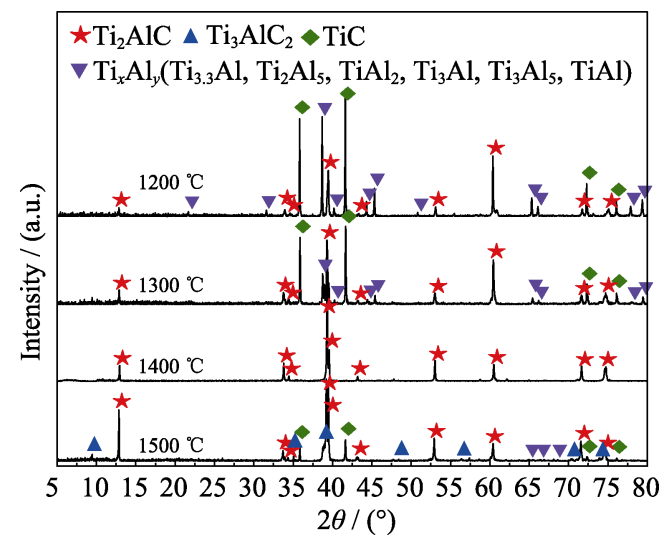

Fig. 4 XRD patterns of $0.95 \mathrm{TiC} / 1.05 \mathrm{Ti} / 1.05 \mathrm{Al}$ sintered at different temperatures

\subsection{Wetting behavior of $\mathrm{Ag} / \mathrm{Ti}_{2} \mathrm{AlC}$}

In the process of heating, the contact angles and optical images of molten $\mathrm{Ag}$ on the $\mathrm{Ti}_{2} \mathrm{AlC}$ substrate are simultaneously recorded, as shown in Fig. 5. The poor wettability of $\mathrm{Ag}$ and $\mathrm{Ti}_{2} \mathrm{AlC}$ is observed at $\sim 990{ }^{\circ} \mathrm{C}$ (a large contact angle of $154.6^{\circ}$ ). As temperature increases, $\mathrm{Al}$ atoms in $\mathrm{Ti}_{2} \mathrm{AlC}$ outward diffuse into $\mathrm{Ag}$ matrix, leading to the reactive wetting and hence the decrease of contact angle. When temperature rises to $1130{ }^{\circ} \mathrm{C}$, the contact angle stabilized at $14.1^{\circ}$, indicating that $\mathrm{Ag}$ well wets $\mathrm{Ti}_{2} \mathrm{AlC}$. In the preparation of $\mathrm{Ag} / \mathrm{Ti}_{2} \mathrm{AlC}$ composite, good wettability is beneficial to enhance the interface bonding between $\mathrm{Ag}$ and $\mathrm{Ti}_{2} \mathrm{AlC}$, and reduce the aggregation of $\mathrm{Ti}_{2} \mathrm{AlC}$ particles. Good wettability also facilitates the viscosity improvement of the molten pool and the increases the resistance to splash of liquid Ag during the electric arc discharging.

\section{3 $\mathrm{Ag} / \mathrm{Ti}_{2} \mathrm{AlC}$ composite}

XRD result of $\mathrm{Ag} / 10 \mathrm{wt} \% \mathrm{Ti}_{2} \mathrm{AlC}(\mathrm{Ag} / 10 \mathrm{TAC})$ composite is shown in Fig. 6. Except $\mathrm{Ag}$ and $\mathrm{Ti}_{2} \mathrm{AlC}$, no other impure phase were detected. The SEM image of Ag/10TAC (Fig. 6(b)) shows the uniform microstructure of the composite, and the good bonding of the $\mathrm{Ti}_{2} \mathrm{AlC}$ with $\mathrm{Ag}$ matrix (Fig. 6(c)), which is attributed to the good wettability between the $\mathrm{Ag}$ and the $\mathrm{Ti}_{2} \mathrm{AlC}$. The basic properties

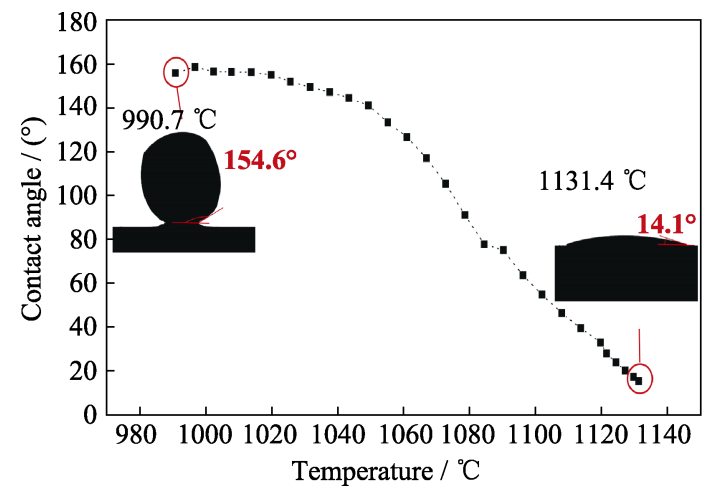

Fig. 5 Contact angles and optical images of $\mathrm{Ag} / \mathrm{Ti}_{2} \mathrm{AlC}$ in the process of heating 
(density, relative density, hardness, resistivity) of $\mathrm{Ag} / 10 \mathrm{TAC}$ composite are listed in Table 4. High relative density $(\sim 95.7 \%)$ and moderate hardness $(96 \mathrm{HV})$ provide good strength and machinability of the Ag/10TAC composite. Low resistivity $(79.5 \mathrm{n} \Omega \cdot \mathrm{m})$ facilitates the electric conducting of current and thus reduces contact resistivity and temperature rise of the $\mathrm{Ag} / 10 \mathrm{TAC}$ contact.

\subsection{Arc erosion resistance of Ag/10TAC}

Arc erosion resistance is an important index to evaluate the application potential of an electrical contact material. As shown in Fig. 7, after 5610 electric arc discharging cycles, the shape of $\mathrm{Ag} / 10 \mathrm{TAC}$ contact remains well (inset of Fig. 7(a)). The erosion area of eroded contact surface accounts for $88.6 \%$ of the total contact area,

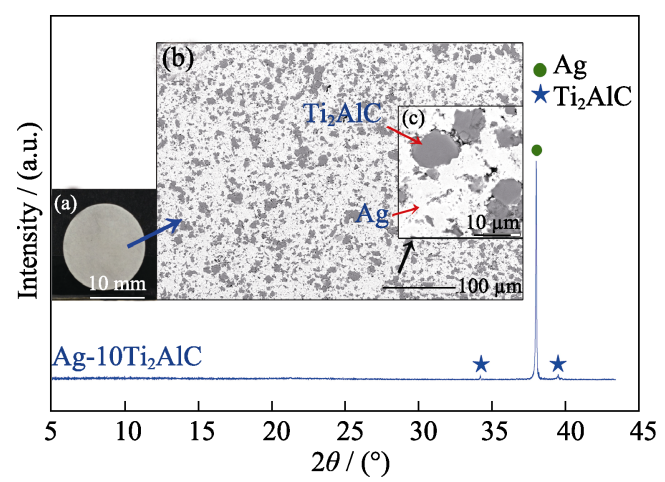

Fig. $6 \mathrm{XRD}$ pattern of $\mathrm{Ag} / 10 \mathrm{TAC}$ composite with insets showing (a) picture of the bulk, (b) microstructure of composite, and (c) the magnified SEM image

Table 4 Basic properties of $\mathrm{Ag} / \mathrm{Ti}_{2} \mathrm{AlC}$ composite

\begin{tabular}{cccc}
\hline $\begin{array}{c}\text { Density/ } \\
\left(\mathrm{g} \cdot \mathrm{cm}^{-3}\right)\end{array}$ & $\begin{array}{c}\text { Relative } \\
\text { density } / \%\end{array}$ & Hardness, HV & $\begin{array}{c}\text { Resistivity/ } \\
(\mathrm{n} \Omega \cdot \mathrm{m})\end{array}$ \\
\hline 8.692 & $95.7 \%$ & 96 & 79.5 \\
\hline
\end{tabular}

(a)
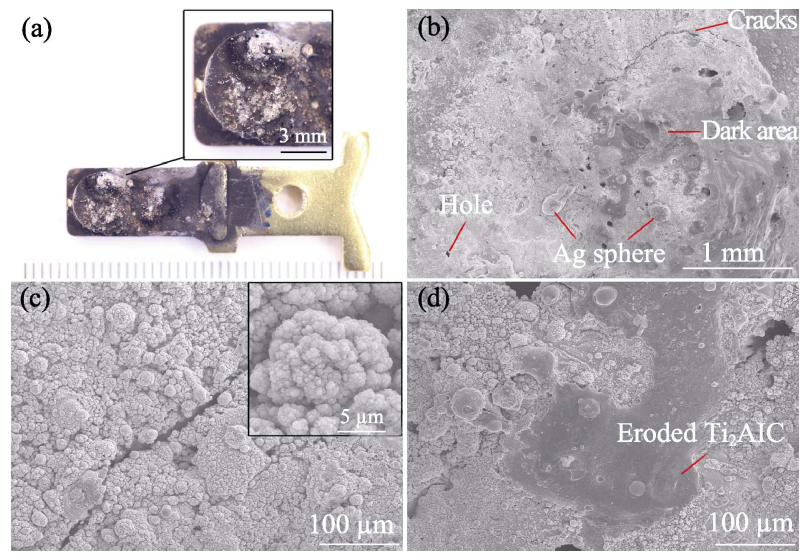

Fig. 7 (a) Optical image of the Ag/10TAC contact after 5610 arc discharging cycles, with magnified SEM image in the inset; (b) SEM image of the contact surface morphology; (c) Morphology of the Ag molten pool, with magnified SEM image of cauliflower-shaped Ag particles in the inset; (d) Magnified SEM image of the aggregated eroded $\mathrm{Ti}_{2} \mathrm{AlC}$ (dark area in (b)) but the mass loss is only $4.4 \mathrm{wt} \%$, indicating that $\mathrm{Ag} / 10 \mathrm{TAC}$ has strong resistance to arc erosion. Fine thermal and low resistivity of $\mathrm{Ti}_{2} \mathrm{AlC}$, good wettability between molten $\mathrm{Ag}$ and $\mathrm{Ti}_{2} \mathrm{AlC}$, and the interdiffusion between $\mathrm{Ag}$ and $\mathrm{Ti}_{2} \mathrm{AlC}$ are responsible for the good contacting properties of the Ag/10TAC composite. After arc erosion, a few cracks, holes, and Ag spheres were observed on the surface of Ag/10TAC contact (Fig. 7(b)). The Ag matrix inside molten pool mainly exhibits cauliflower-shaped after arc erosion, as shown in inset of Fig. 7(c). In addition, some dark areas were observed on the contact surface (Fig. 7(b, d)), which mainly contains Ti, O, C, and little Al by EDS. The formation of these dark areas is attributed to the aggregation of the eroded $\mathrm{Ti}_{2} \mathrm{AlC}$, which has been partially destroyed by high-temperature oxidation during electric arc discharging.

\section{Conclusions}

Pressureless synthesis was employed to study the effect of composition and sintering temperature on the purity and morphology of $\mathrm{Ti}_{2} \mathrm{AlC}$ powder. The structure and properties of the Ag/10TAC composite electrical contact material are investigated. Main conclusions are drawn as follows:

1) High-purity $\mathrm{Ti}_{2} \mathrm{AlC}$ powder $(99.2 \%)$ is synthesized at $1400{ }^{\circ} \mathrm{C} / \mathrm{h}$ by using the raw powder with the starting composition of $0.95 \mathrm{TiC} / 1.05 \mathrm{Ti} / 1.05 \mathrm{Al}$.

2) Contact angle decreases with temperature increasing, due to the reactive wetting between molten $\mathrm{Ag}$ and $\mathrm{Ti}_{2} \mathrm{AlC}$. Small contact angle $\left(14^{\circ}\right)$ is obtained at $1130{ }^{\circ} \mathrm{C}$. Good wettability facilitates the preparation and improves the arc erosion resistance of $\mathrm{Ag} / \mathrm{Ti}_{2} \mathrm{AlC}$.

3) $\mathrm{Ag} / 10 \mathrm{TAC}$ composite exhibits uniform structure, high density, moderate hardness, low resistivity, and favorable arc erosion resistance.

4) $\mathrm{Ti}_{2} \mathrm{AlC}$ has been proven experimentally to be a promising reinforcement for Ag-based electric contact material.

\section{References:}

[1] WINDRED G. Electrical contact resistance. Journal of the Franklin Institute, 1941, 231(6): 547-585.

[2] HOLM R, HOLM E. Electric Contacts Handbook. Berlin: Springer, 1958.

[3] COSOVIC V, COSOVIC A, TALIJAN N, et al. State of the art and challenges in development of electrical contact materials in the light of the RoHS directive. Science of Sintering, 2012, 44(2): $245-253$.

[4] SLADE P G. Effect of high temperature on the release of heavy metals from $\mathrm{AgCdO}$ and $\mathrm{AgSnO}_{2}$ contacts. IEEE Transactions on Components, Hybrids, and Manufacturing Technology, 1989, 12(1): $5-15$. 
[5] SCHRODER K H. Silver-metal oxides as contact materials. IEEE Transactions on Components, Hybrids, and Manufacturing Technology, 1987, 10(1): 127-134.

[6] WU C P, YI D Q, LI J, et al. Investigation on microstructure and performance of $\mathrm{Ag} / \mathrm{ZnO}$ contact material. Journal of Alloys and Compounds, 2008, 457(1/2): 565-570.

[7] ZHOU X L, CAO J C, CHEN J C, et al. Micro-superplastic behavior of copper oxide in $\mathrm{AgCuO}$ composites. Rare Metal Materials and Engineering, 2013, 42(11): 2242-2244.

[8] WOJCIK-GRZYBEK D, FRYDMAN K, BORKOWSKI P. The influence of the microstructure on the switching properties of $\mathrm{Ag} \mathrm{C}$, Ag-WC-C and Ag-WC contact materials. Archives of Metallurgy and Materials, 2013, 58(4): 1059-1065.

[9] WU C P, YI D Q, WENG W, et al. Arc erosion behavior of Ag/Ni electrical contact materials. Materials \& Design, 2015, 85: 511-519.

[10] BARSOUM M W. The $\mathrm{M}_{N+1} \mathrm{AX}_{N}$ phases: a new class of solids; thermodynamically stable nanolaminates. Progress in Solid State Chemistry, 2000, 28(1-4): 201-281.

[11] SUN Z M. Progress in research and development on MAX phases: a family of layered ternary compounds. International Materials Reviews, 2011, 56(3): 143-166.

[12] ZHANG M, TIAN W B, ZHANG P G, et al. Microstructure and properties of $\mathrm{Ag}-\mathrm{Ti}_{3} \mathrm{SiC}_{2}$ contact materials prepared by pressureless sintering. International Journal of Minerals, Metallurgy, and Materials, 2018, 25(7): 810-816.

[13] DING J X, TIAN W B, ZHANG P G, et al. Arc erosion behavior of $\mathrm{Ag} / \mathrm{Ti}_{3} \mathrm{AlC}_{2}$ electrical contact materials. Journal of Alloys and Compounds, 2018, 740: 669-676.

[14] DING J X, TIAN W B, WANG D D, et al. Corrosion and degradation mechanism of $\mathrm{Ag} / \mathrm{Ti}_{3} \mathrm{AlC}_{2}$ composites under dynamic electric arc discharging. Corrosion Science, 2019, 156: 147-160.

[15] WANG D D, TIAN W B, MA A B, et al. Anisotropic properties of $\mathrm{Ag} / \mathrm{Ti}_{3} \mathrm{AlC}_{2}$ electrical contact materials prepared by equal channel angular pressing. Journal of Alloys and Compounds, 2019, 784: 431-438.

[16] LIU M M, CHEN J L, CUI H, et al. Ag/ $/ \mathrm{Ti}_{3} \mathrm{AlC}_{2}$ composites with high hardness, high strength and high conductivity. Materials Letters, 2018, 213: 269-273.

[17] DING J X, TIAN W B, ZHANG P G, et al. Preparation and arc erosion properties of $\mathrm{Ag} / \mathrm{Ti}_{2} \mathrm{SnC}$ composites under electric arc discharging. Journal of Advanced Ceramics, 2019, 8(1): 90-101.

[18] DING J X, TIAN W B, WANG D D, et al. Microstructure evolution, oxidation behavior and corrosion mechanism of $\mathrm{Ag} / \mathrm{Ti}_{2} \mathrm{SnC}$ composite during dynamic electric arc discharging. Journal of Alloys and Compounds, 2019, 785: 1086-1096.

[19] ZHU J F, GAO J Q, YANG J F, et al. Synthesis and microstructure of layered-ternary $\mathrm{Ti}_{2} \mathrm{AlC}$ ceramic by high energy milling and hot pressing. Materials Science and Engineering A, 2008, 490(1/2): $62-65$.

[20] BAI Y L, ZHANG H X, HE X D, et al. Growth morphology and microstructural characterization of nonstoichiometric $\mathrm{Ti}_{2} \mathrm{AlC}$ bulk synthesized by self-propagating high temperature combustion synthesis with pseudo hot isostatic pressing. International Journal of Refractory Metals and Hard Materials, 2014, 45: 58-63.

[21] ZHOU W B, MEI B C, ZHU J Q, et al. Rapid synthesis of $\mathrm{Ti}_{2} \mathrm{AlC}$ by spark plasma sintering technique. Materials Letters, 2005, 59(1): 131-134.

[22] LIANG B Y, WANG M Z, LI X P, et al. Synthesis of Ti ${ }_{2} \mathrm{AlC}$ by laserinduced self-propagating high-temperature sintering. Journal of Alloys and Compounds, 2010, 501(1): L1-L3.

[23] LIU W, BO T Z, XIE Z P, et al. Fabrication of injection moulded translucent alumina ceramics via pressureless sintering. Advances in Applied Ceramics, 2011, 110(4): 251-254.

[24] YEH C L, SHEN Y G. Combustion synthesis of $\mathrm{Ti}_{3} \mathrm{AlC}_{2}$ from $\mathrm{Ti} / \mathrm{Al} / \mathrm{C} / \mathrm{TiC}$ powder compacts. Journal of Alloys and Compounds, 2008, 466: 308-313.

\section{高纯 $\mathrm{Ti}_{2} \mathrm{AlC}$ 粉末的无压制备及其在 $\mathrm{Ag}$ 基电触头材料的应用}

\section{丁健翔 ${ }^{1}$, 黄培艳 ${ }^{1}$, 查余辉 ${ }^{1}$, 汪丹丹 ${ }^{2}$, 张培根 ${ }^{2}$, 田无边 ${ }^{2}$, 孙正明 ${ }^{2}$}

(1. 安徽工业大学 材料科学与工程学院, 先进金属材料绿色制备与表面技术教育部重点实验室, 马鞍山 243002;

2. 东南大学 材料科学与工程学院, 南京 211189)

摘 要: $\mathrm{Ag}$ 基电触头是低压开关的“心脏”, 触头无 $\mathrm{Cd}$ 化一直困扰着人们, 寻找新型环保电触头材料是目前低压开关 领域研究的重点。本研究从 $\mathrm{Ag}$ 基电触头增强相材料设计入手, 利用简单快速的无压技术合成了高纯 $\mathrm{Ti}_{2} \mathrm{AlC}_{\mathrm{C}}$ 粉末 (99.2\%), 制备的 $\mathrm{Ag} / \mathrm{Ti}_{2} \mathrm{AlC}$ 复合电触头材料组织均匀、 $\mathrm{Ti}_{2} \mathrm{AlC}$ 颗粒与 $\mathrm{Ag}$ 基体结合紧密、相对密度高( $\left.95.7 \%\right) 、$ 硬 度适中 $(96 \mathrm{HV})$ 、导电性好(电阻率低至 $79.5 \mathrm{n} \Omega \cdot \mathrm{m}$ )、抗电弧侵蚀性能优良(5610 次电弧放电后触头质量损失仅为 $4.4 \mathrm{wt} \%)$ 。 $\mathrm{Ag} / \mathrm{Ti}_{2} \mathrm{AlC}$ 优良的结构和性能主要归因于 $\mathrm{Ti}_{2} \mathrm{AlC}$ 本身的导电导热性能和 $\mathrm{Ag} / \mathrm{Ti}_{2} \mathrm{AlC}$ 之间的润湿性。该复 合材料在进一步深入研究后, 有望大面积应用并替代传统电触头材料。

关 键 词: $\mathrm{Ti}_{2} \mathrm{AlC}$; 电触头; 金属陶瓷复合; 导电性; 润湿性; 抗电弧侵蚀 中图分类号: TG148 文献标识码: A 